IFAS Extension

\title{
Puss Caterpillar (Larva), Southern Flannel Moth (Adult), Megalopyge opercularis (J. E. Smith 1797) (Insecta: Lepidoptera: Zygaenoidea: Megalopygidae) ${ }^{1}$
}

\author{
Donald W. Hall ${ }^{2}$
}

\section{Introduction}

The southern flannel moth, Megalopyge opercularis (J. E. Smith) (Insecta: Lepidoptera: Zygaenoidea: Megalopygidae), is an attractive small moth that is bestknown because of its larva, the puss caterpillar, which is one of the most venomous caterpillars in the United States (Bishopp 1923, El-Mallakh et al. 1986, Hossler 2010, Khalaf 1975).

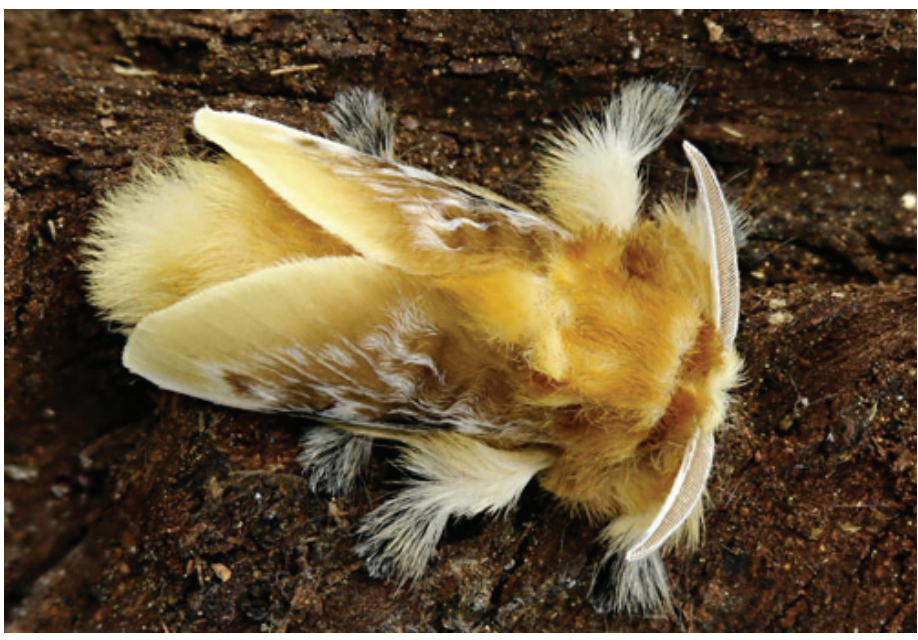

Figure 1. Male southern flannel moth, Megalopyge opercularis (dorsal view).

Credits: Donald W. Hall, University of Florida.

The family name Megalopygidae and genus name Megalopyge are derived from the Greek roots Megalo (large) and

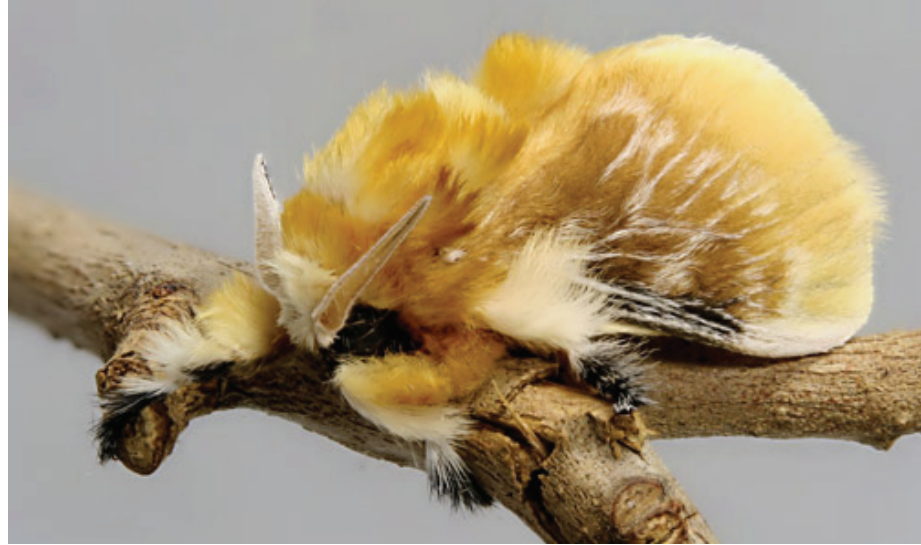

Figure 2. Male southern flannel moth, Megalopyge opercularis (anterior lateral view).

Credits: Donald W. Hall, University of Florida.

pygidium (rump) - probably because of the shape of the caterpillars. The specific epithet, opercularis, is derived from the Latin word operculum (Borror 1960) and refers to the lid (door) on the cocoon. The name "puss caterpillar" is likely in reference to the caterpillar's resemblance to a cat with its soft fur and tail.

The southern flannel moth was originally described by J. E. Smith (1797) and named Phalaena opercularis (common name, waved yellow egger moth). For a historical account of the southern flannel moth's taxonomy see Heppner (2003). In addition to the name "puss caterpillar," its caterpillar has

1. This document is EENY-545, one of a series of the Entomology and Nematology Department, Florida Cooperative Extension Service, Institute of Food and Agricultural Sciences, University of Florida. Original publication date January 2012. Revised March 2013. Visit the EDIS website at http://edis.ifas. ufl.edu.

2. Donald W. Hall, professor, Entomology and Nematology Department, Institute of Food and Agricultural Sciences, University of Florida, Gainesville, FL 32611. 


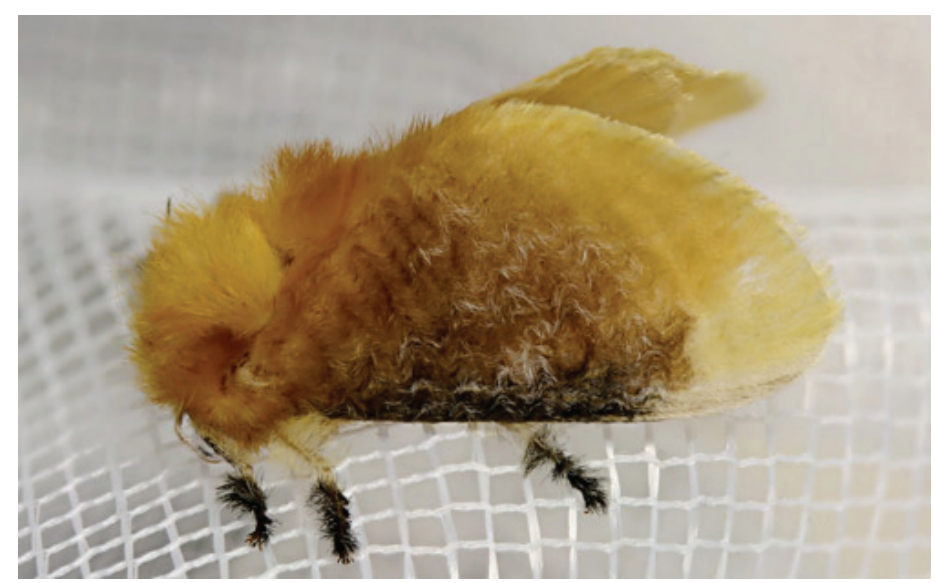

Figure 3. Female southern flannel moth, Megalopyge opercularis (lateral view).

Credits: Donald W. Hall, University of Florida.

been called "Italian asp," "possum bug," "perrito" (Spanish for puppy or little dog) (Bishopp 1923), and "woolly slug" (El-Mallakh et al. 1986).

The southern flannel moth is the most common of the five species of megalopygids found in the southeastern United States.

\section{Distribution}

The southern flannel moth is found from New Jersey to Florida and west to Arkansas and Texas (Covell 2005). It is common in Florida but reaches its greatest abundance in Texas from Dallas southward in the western central part of the state (Bishopp 1923).

\section{Description}

Adults: Adults are small moths with wingspans of 2.4 to $3.6 \mathrm{~cm}$ (approximately 1 to $1.5 \mathrm{in}$ ) (Covell 2005). Females are larger than males. The front wings are yellow with some black along the costal margins and waves of white hair-like

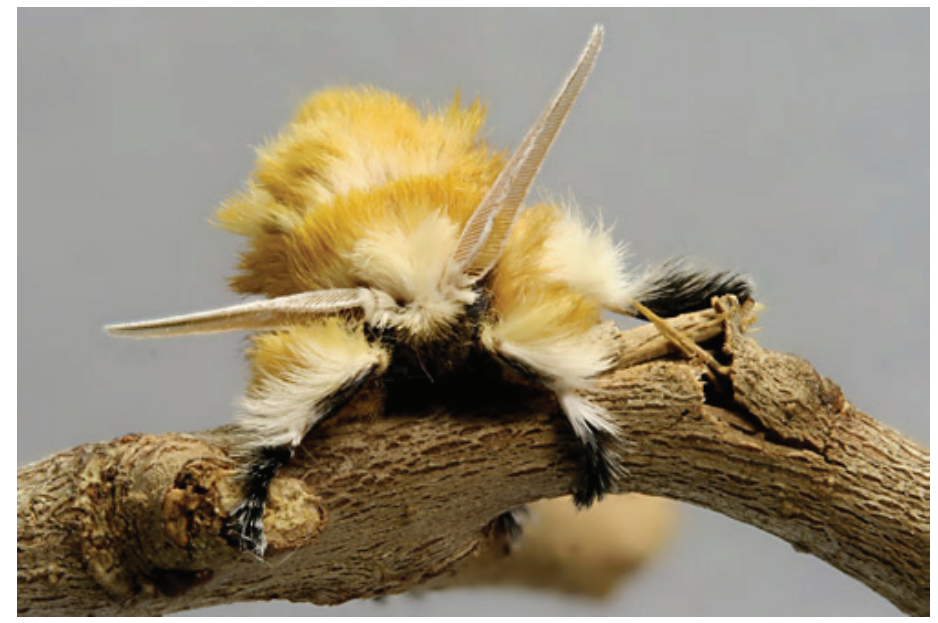

Figure 4. Male southern flannel moth, Megalopyge opercularis (anterior view).

Credits: Donald W. Hall, University of Florida. setae (scales) on the basal 2/3 of the wings. Khalaf (1984) demonstrated that the hair-like setae are actually deeply divided scales and that the undivided bases of the scales are typical of wing scales of other moths. The black color is more pronounced in males. Hind wings of both sexes are uniformly creamy-yellow. The common name "flannel moth" is due to the thick coating of fur-like setae on the bodies which is predominantly orange on the thorax.

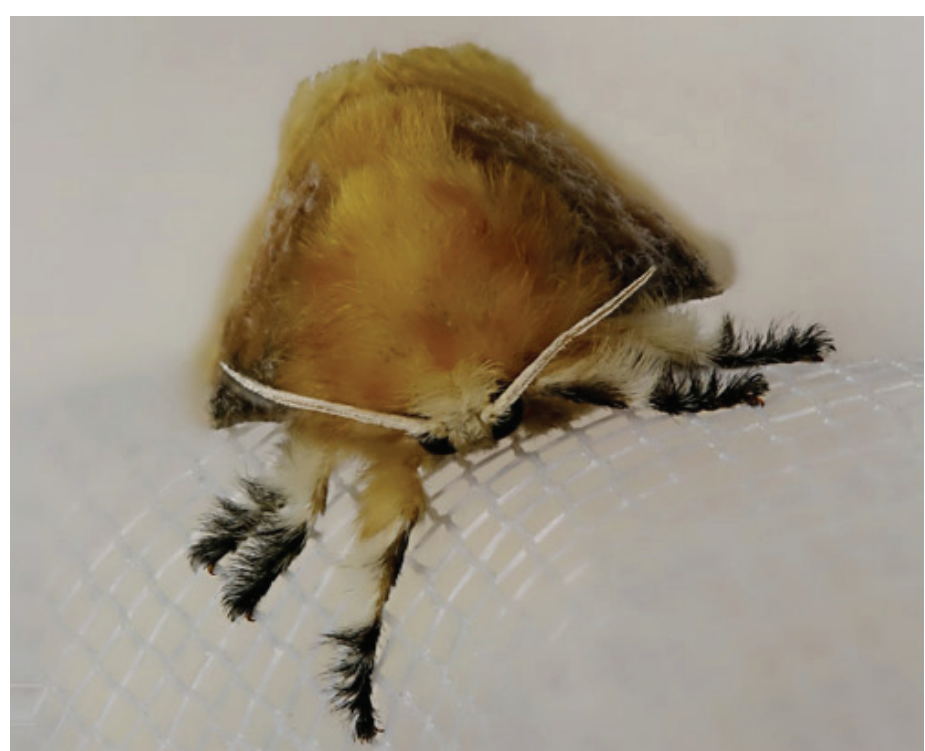

Figure 5. Adult female southern flannel moth, Megalopyge opercularis (anterior view).

Credits: Donald W. Hall, University of Florida.

Antennae are bipectinate (comb-like) with rami (teeth) on two sides. Rami of antennae of males (Figures 1, 2, and 4) are much longer than those of antennae of females (Figures 3 and 5). The rami of the antennae of females are so short that the antennae appear almost thread-like.

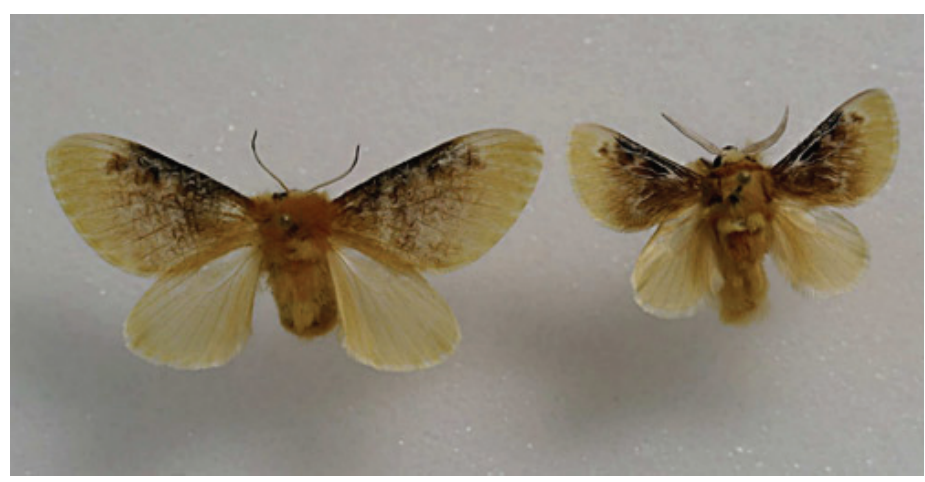

Figure 6. Female and male southern flannel moths, Megalopyge opercularis.

Credits: Donald W. Hall, University of Florida.

Eggs: The light yellow eggs average $1.2 \mathrm{~mm}$ in length and $0.6 \mathrm{~mm}$ in width (Bishopp 1923) and are slightly rounded on the ends. 


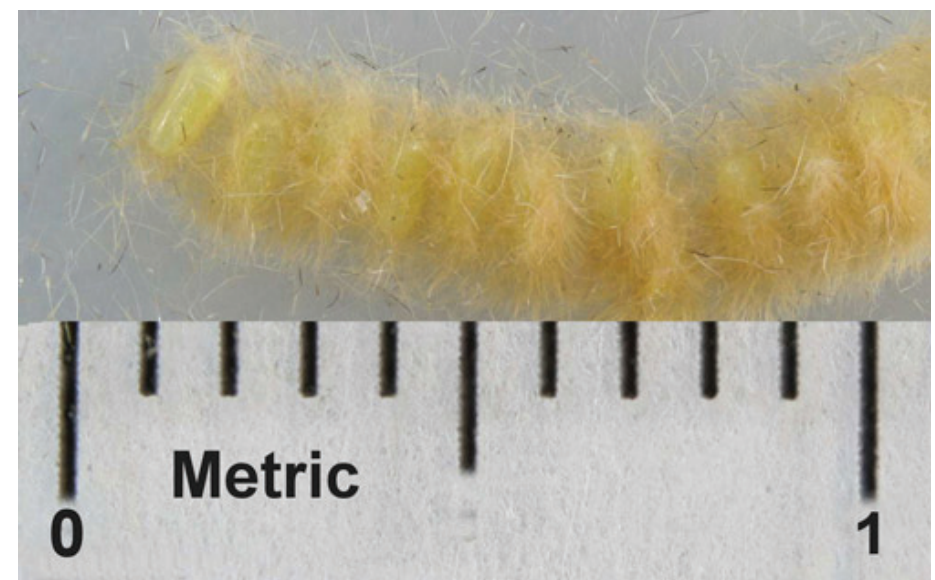

Figure 7. Eggs of the southern flannel moth, Megalopyge opercularis. Credits: Donald W. Hall, University of Florida.

Larvae: The number of instars is uncertain and may be variable. Bishop (1923) stated that there are probably five or six instars, and gave the following approximate lengths for the first four and last instars: 1st instar: $1.5 \mathrm{~mm}$; 2nd instar: $2.3 \mathrm{~mm}$; 3rd instar; $3.1 \mathrm{~mm}$; 4 th instar: $3.6 \mathrm{~mm}$; mature larva: $2.54 \mathrm{~cm}$ (1 inch). Davidson (1967) reported similar dimensions. It seems that there may have been a misidentification of later instars by these authors based on the huge size difference reported between the fourth and final instars. Khalaf (1975) reported that there are 8 to 10 instars.

Full-grown larvae, including the ones in Figures 13 to 15 reared by the author on winged elm, Ulmus alata Michaux, were much larger and measured approximately $3.5 \mathrm{~cm}(1.4$ inches) in body length and $4.0 \mathrm{~cm}$ (1.6 inches) including the tail.

The integument of first and second instars is yellow but becomes pale greenish white to white in later instars. Larvae become progressively more "hairy" with each molt. All instars have rows of verrucae (raised sclerites with radiating setae [Gordh and Headrick 2001]) that bear hollow spines each of which has a venom gland at its base (Foot 1922). The spines are obscured by the long soft setae in the late instars. Late instars have a hairy tail. The color of late instars is somewhat variable.

In the photographs of larvae that follow, only the first, next-to-last, and last instars are known for certain. The other larvae are in increasing order of maturity, but their exact instar in not known.

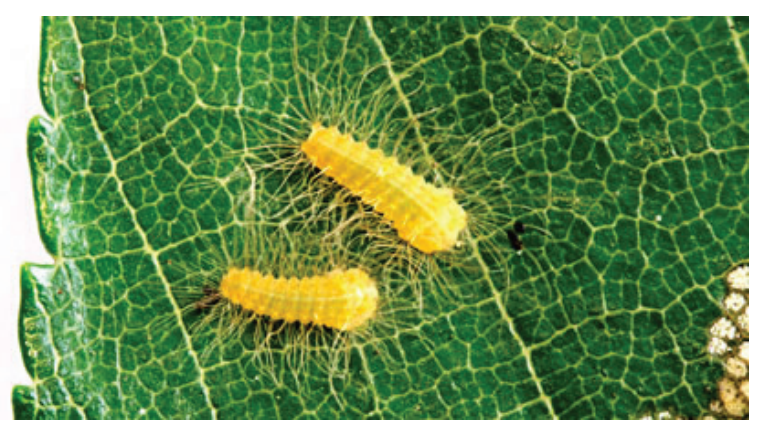

Figure 8. Puss caterpillars, Megalopyge opercularis (first instars). Credits: Donald W. Hall, University of Florida.

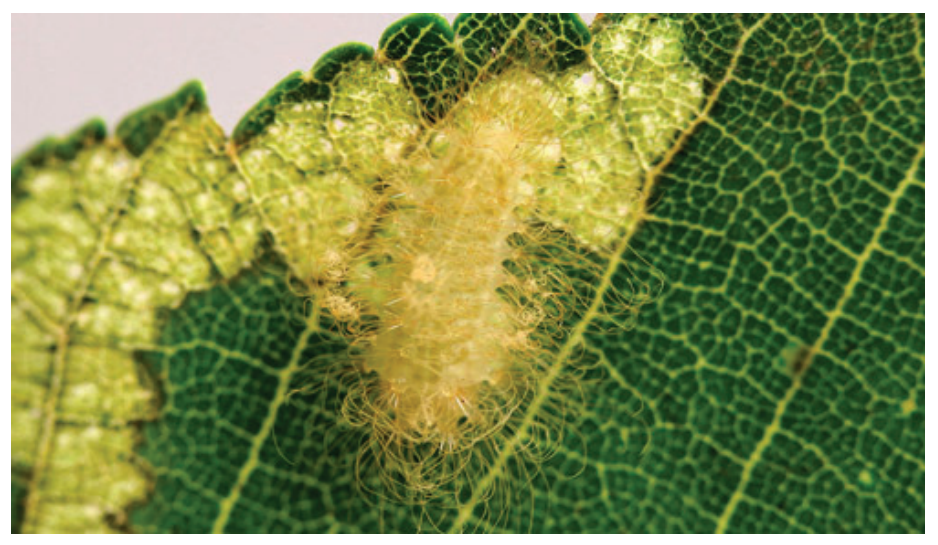

Figure 9. Puss caterpillar, Megalopyge opercularis (early instar). Credits: Donald W. Hall, University of Florida.

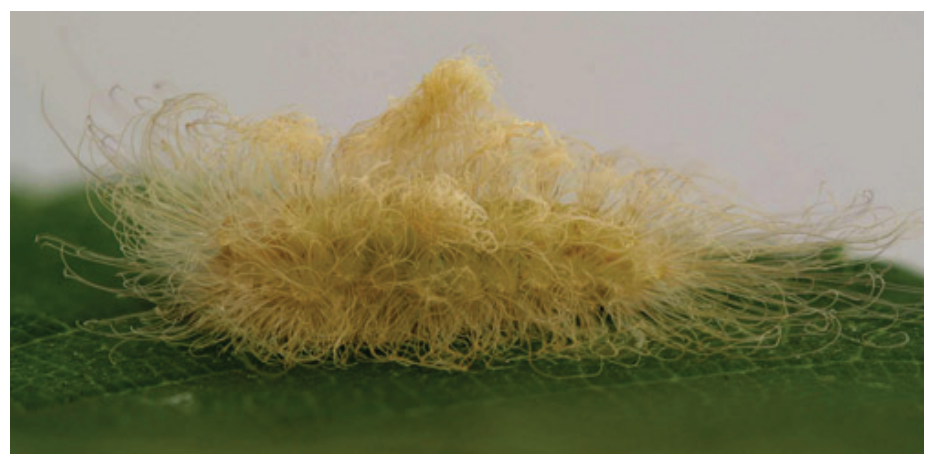

Figure 10. Puss caterpillar, Megalopyge opercularis (middle instar). Credits: Donald W. Hall, University of Florida.

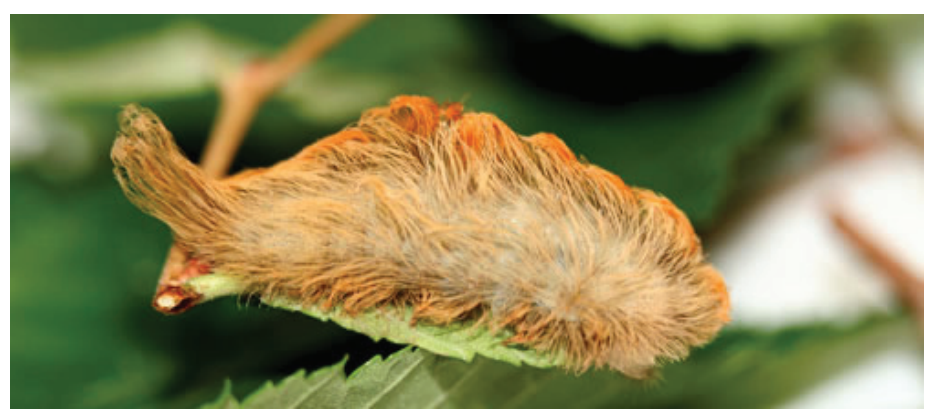

Figure 11. Puss caterpillar, Megalopyge opercularis (middle instar). Credits: Donald W. Hall, University of Florida. 


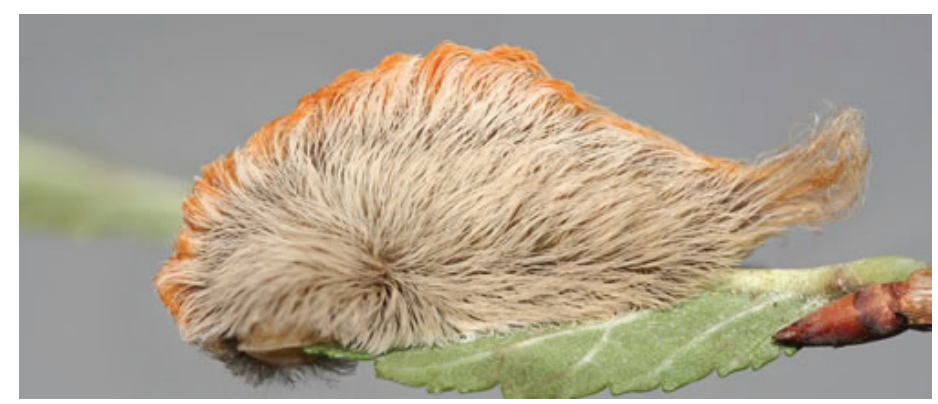

Figure 12. Puss caterpillar, Megalopyge opercularis (next to last instar). Credits: Donald W. Hall, University of Florida.

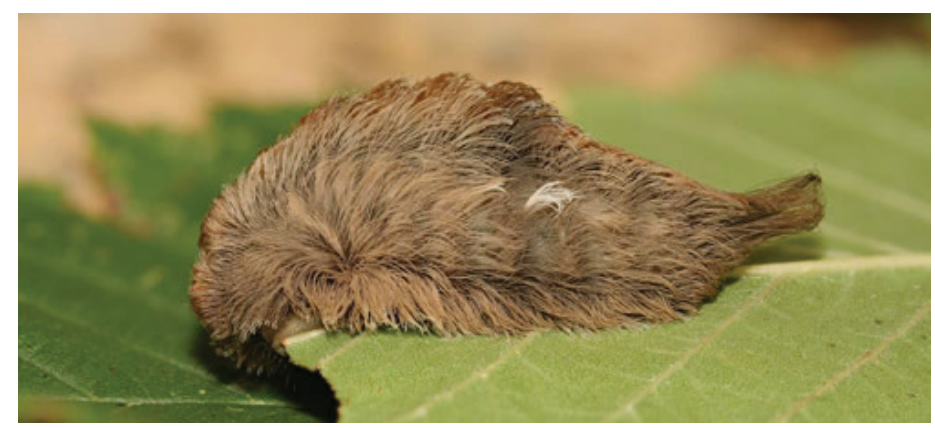

Figure 13. Puss caterpillar, Megalopyge opercularis (last instar). Credits: Donald W. Hall, University of Florida.

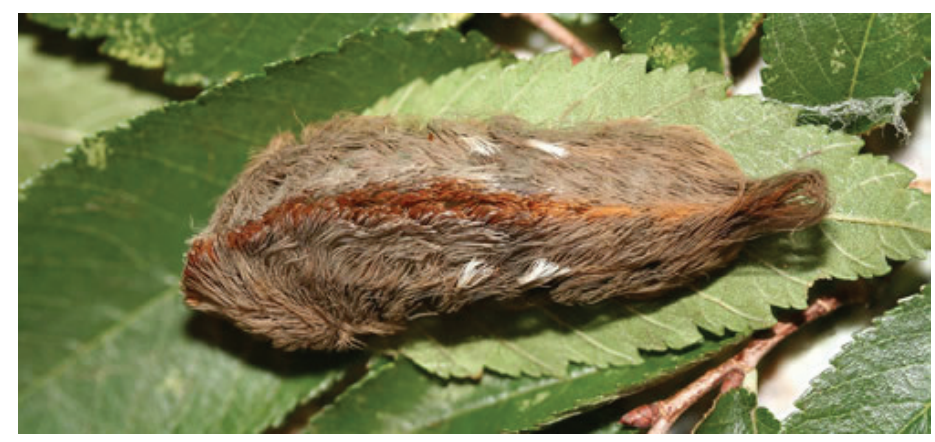

Figure 14. Puss caterpillar, Megalopyge opercularis (last instar, dorsal view).

Credits: Donald W. Hall, University of Florida.

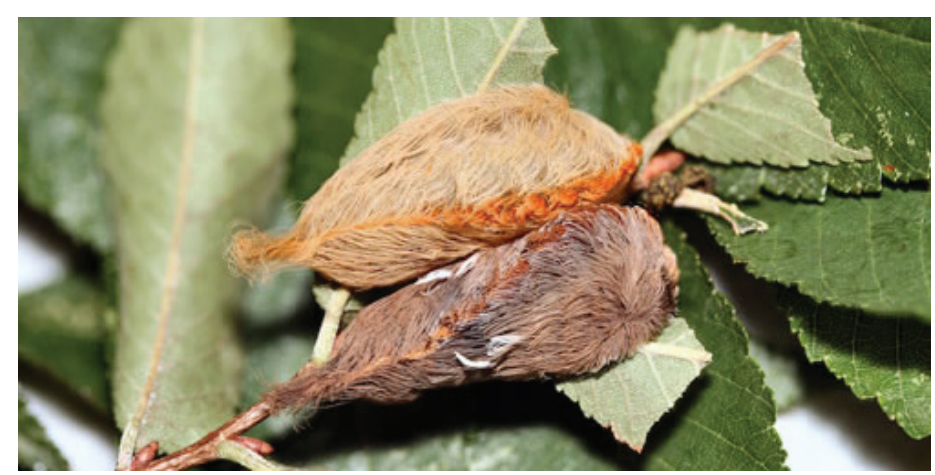

Figure 15. Puss caterpillars, Megalopyge opercularis (next to last [top] and last instars).

Credits: Donald W. Hall, University of Florida.
The bodies of late instar puss caterpillars are normally completely hidden from sight by the thick coating of hair (setae). However, the head and prothorax may be exposed when the larvae are moving about or occasionally when feeding.

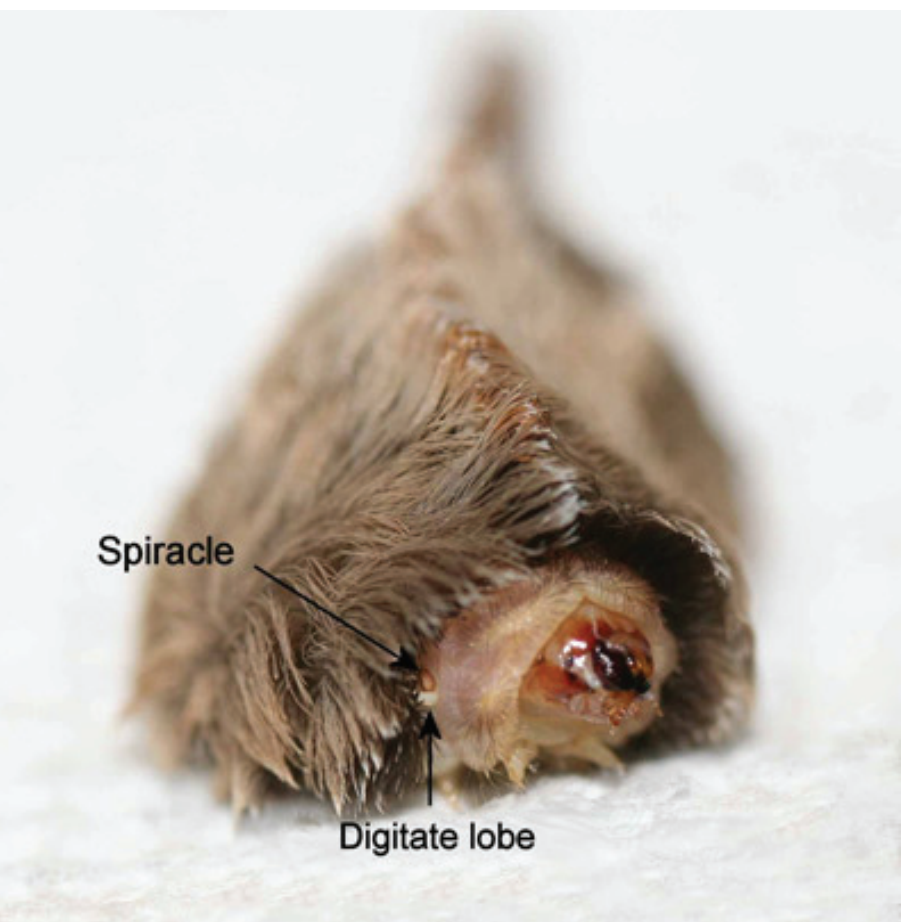

Figure 16. Puss caterpillar, Megalopyge opercularis (anterior view showing head, prothorax, prothoracic spiracle and pre-spiracular appendage).

Credits: Donald W. Hall, University of Florida.

Unlike most other moth larvae, megalopygid larvae have seven pairs of prolegs. Megalopygids have accessory prolegs on abdominal segments two and seven in addition to the normal complement of prolegs on abdominal segments three through six and ten. The accessory prolegs of all North American species of megalopygids, including the puss caterpillar, have no crochets (Stehr 1987, Wagner 2005).

Megalopygid larvae also have post-spiracular appendages (Figure 26) (=digitate sensilla of Epstein [1996]) on the abdominal segments that are hidden by the thick coat of setae. A defensive function was assigned to these structures by Hoffman (1932 [cited by Epstein 1996]) who reported that stimulation in the area of the "sensilla" resulted in the larva moving both the sub-dorsal and lateral spine-bearing verrucae toward the spiracles. 


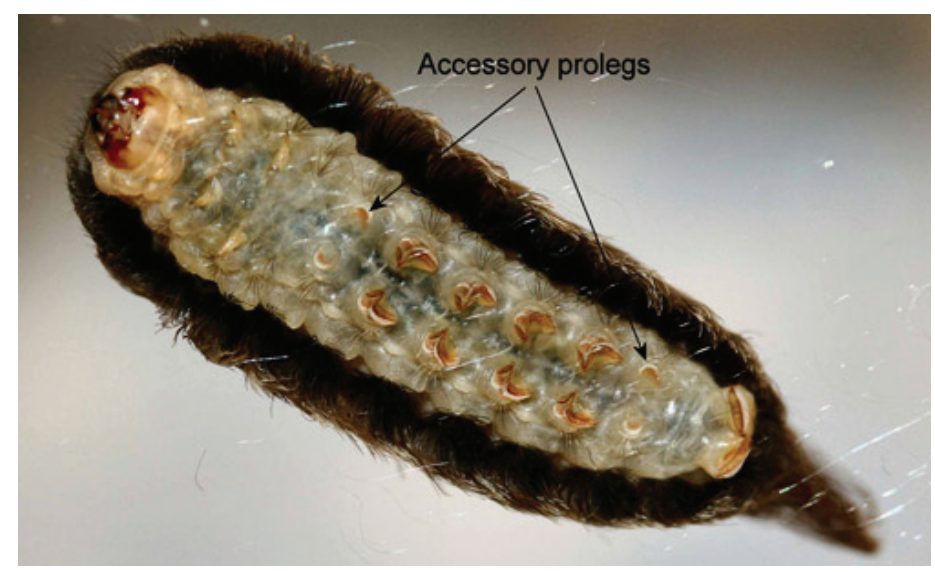

Figure 17. Puss caterpillar, Megalopyge opercularis (ventral view showing auxillary prolegs without crochets).

Credits: Donald W. Hall, University of Florida.

Cocoons: The cocoons vary in size from $1.3 \mathrm{~cm}$ to $2.0 \mathrm{~cm}$. They have a small hump (hair pocket) on the back, and the flattened front end is formed by the operculum. Newly spun cocoons have a thin tapering front that extends beyond the operculum. As the cocoon ages and weathers, this front part collapses to form a flattened silk pad on the substrate in front of the operculum. The only apparent function of this ephemeral front part is to maintain structural integrity of the cocoon until the operculum is finished.

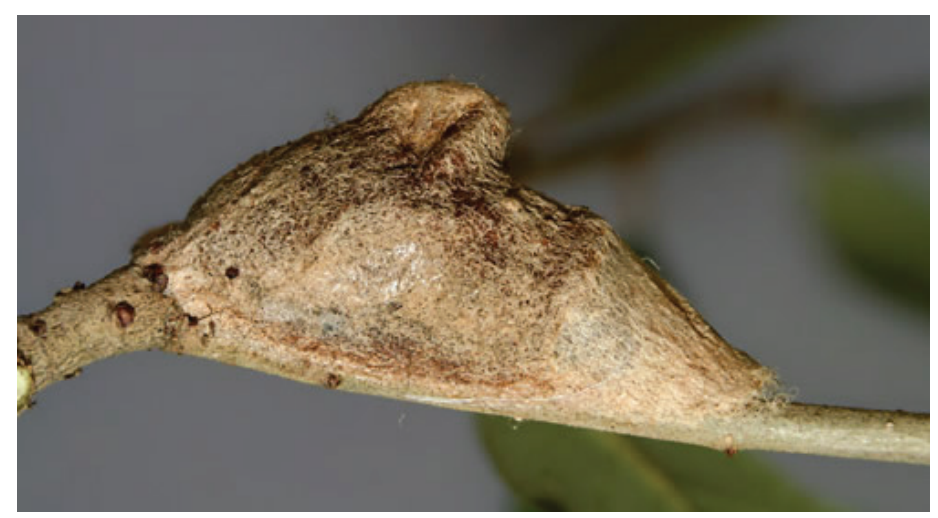

Figure 18. Southern flannel moth cocoon, Megalopyge opercularis (new cocoon with thin silk anterior structure).

Credits: Donald W. Hall, University of Florida.

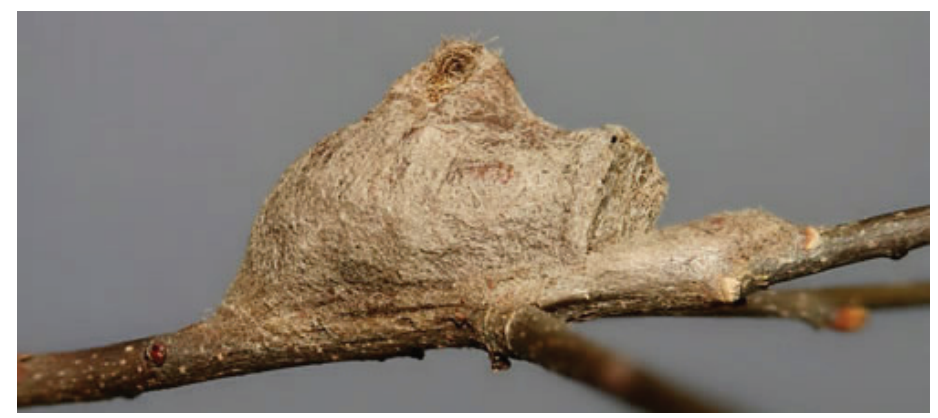

Figure 19. Southern flannel moth cocoon, Megalopyge opercularis (older weathered cocoon showing operculum and hump). Credits: Donald W. Hall, University of Florida.
Cocoons are extremely tough and persist on trees long after the moth has emerged. Some persist long enough to become covered with lichens.

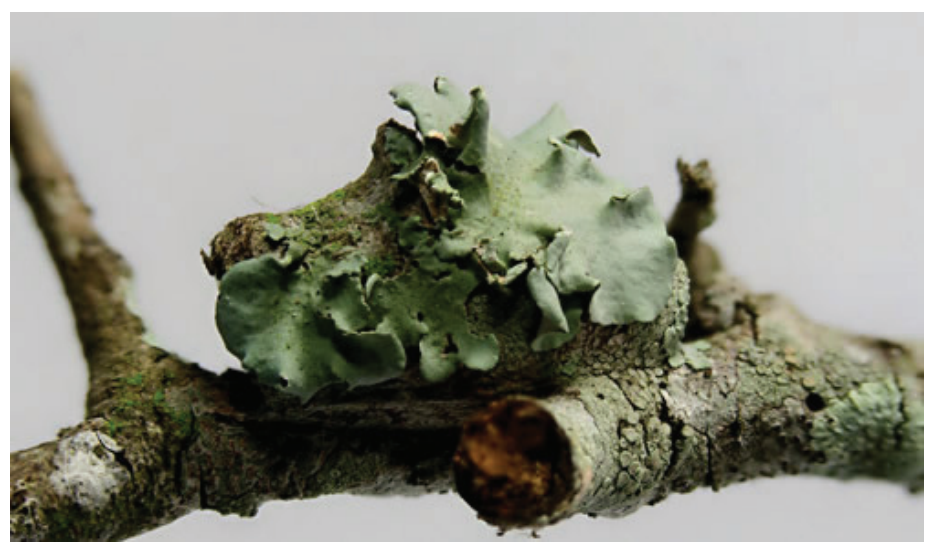

Figure 20. Southern flannel moth cocoon, Megalopyge opercularis (old cocoon covered with lichens).

Credits: Donald W. Hall, University of Florida.

Pupae: Unlike pupae of most moth families, abdominal segments four to six of the pupae are movable in the Megalopygidae and their close relatives including the Limacodidae. The appendages of the pupae are appressed to the surface of the bodies but are neither cemented to the body nor to each other (Mosher 1916). According to Mosher (1916), the "glazed eyepieces" of megalopygid pupae are probably the actual eyes of the pupa, and the "sculptured eyepieces" are likely extensions of the vertex rather than parts of the eyes.

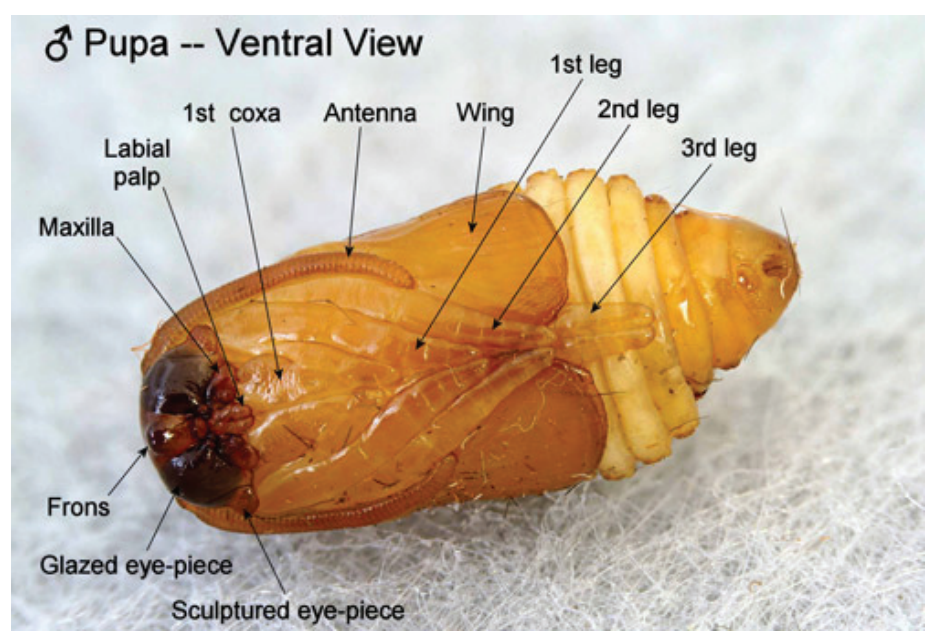

Figure 21. Southern flannel moth pupa, Megalopyge opercularis, (male, ventral view showing appendages and eyepieces).

Credits: Donald W. Hall, University of Florida.

Anterior bands of spines are present on the dorsal aspect of the pupal abdominal segments. 


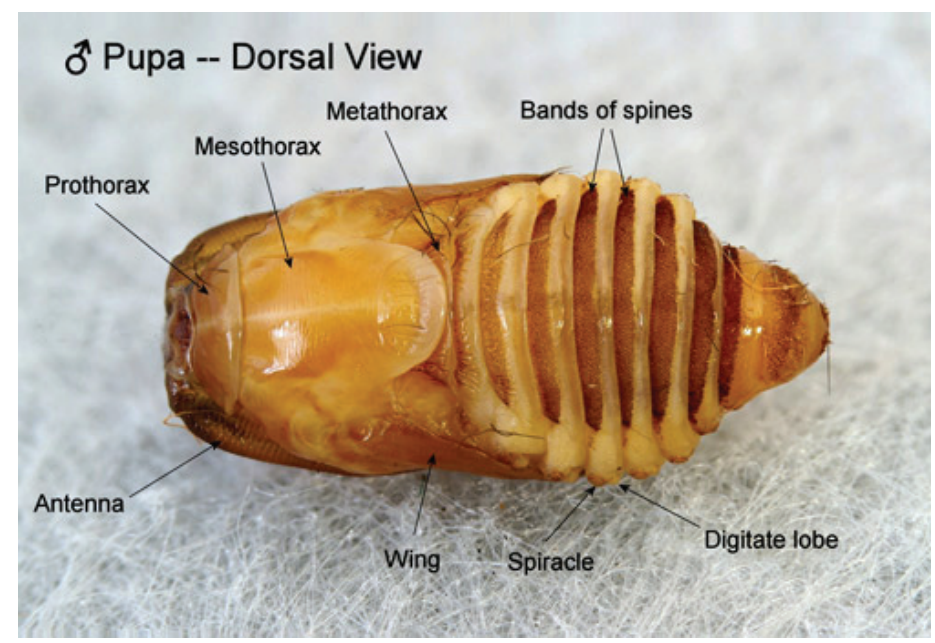

Figure 22. Southern flannel moth pupa, Megalopyge opercularis, (male, dorsal view showing bands of spines on the abdominal segments). Credits: Donald W. Hall, University of Florida.

The post-spiracular appendages from the larval stage are retained in the pupae, but are reduced to button-like structures.

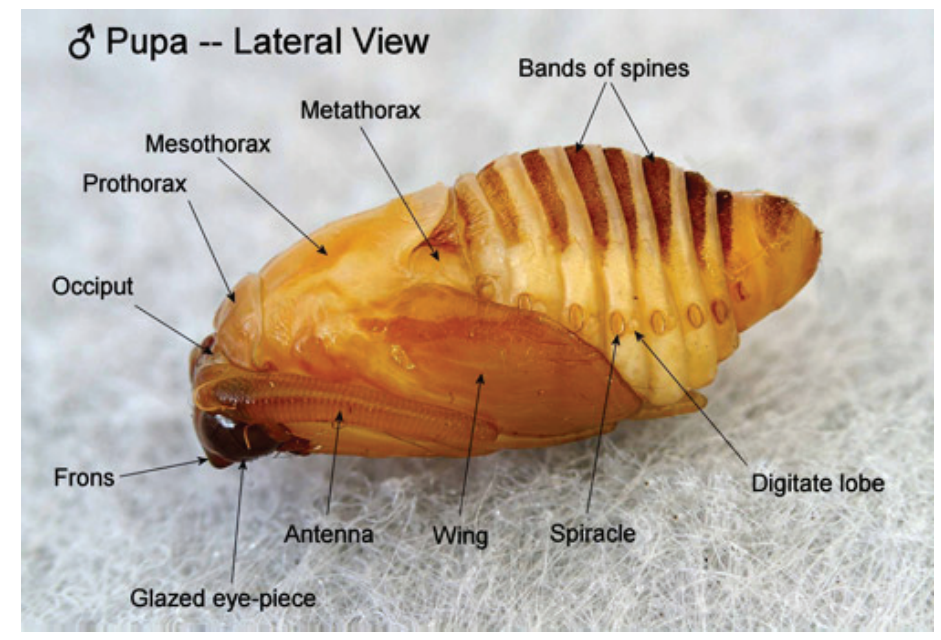

Figure 23. Southern flannel moth pupa, Megalopyge opercularis, (male, lateral view showing abdominal post-spiracular appendages).

Credits: Donald W. Hall, University of Florida.

\section{Life Cycle and Biology}

The southern flannel moth is bivoltine (has two broods per year) with a possible partial third brood in the Deep South (Khalaf 1975). Eagleman (2008) presented epidemiological evidence for two major broods by plotting the chronological distribution of puss caterpillar envenomations for a three year period. His data showed two distinct peaks - one developing in early summer and the second in the fall.

Females usually mate the night of emergence and lay their eggs during the first two nights following mating. Eggs are laid in single or double curved rows (occasionally in patches) on foliage or small twigs and are covered with hair from the under side of abdomen of the female. Eggs hatch in six to eight days.

Larvae of the southern flannel moth are polyphagous (Heppner 1997) and are recorded from plant species belonging to 41 genera (Heppner 2003). Some host records may be erroneous. Like many other Lepidoptera larvae, mature puss caterpillars sometimes wander from the host plant and onto other nearby plants prior to spinning their cocoons. Cocoons may even be found on buildings.

In north central Florida, puss caterpillars are most common on various species of oaks but are also common on elms including both native species and the exotic Chinese elm, Ulmus parvifolia Jacquin. Young larvae feed by skeletonizing leaves (Figure 9) and later eat small holes in the leaves. Late instars are leaf-edge feeders and curl the front of the thorax over the leaves as they feed (Figures 12 and 13). Khalaf (1974) reared larvae on a wheat germ artificial diet and reported ranges of times required for development of two different sets of first generation larvae of 63 to 97 and 53 to 87 days.

Larvae pictured here were reared in an un-air-conditioned garage during the heat of the summer and were fed foliage of winged elm (Ulmus alata Michaux). The first larva to complete development began to spin its cocoon 46 days after hatching from the egg. Micks (1956) reared larvae at $25^{\circ} \mathrm{C}$ on yaupon holly (Ilex vomitoria Aiton), and reported that larval development required about six weeks.

Mature larvae begin to spin their cocoons by making a thin framework of silk using their hair covering as the supporting framework. Cocoons are found on small twigs and branches and also in deep furrows of bark or under loose bark. Some larvae wander off the host plant and are often found on adjacent buildings.

After the outer layer of silk is laid down, larvae remove the soft hair from their bodies and pack it into the hump at the top of the cocoon and then add another inner layer to the cocoon. Larvae of the first generation pupate approximately 16 days after completing the cocoon and begin emerging as adults approximately two weeks later. Individuals of the fall generation overwinter as larvae (prepupae) and pupate in late spring of the next year. 


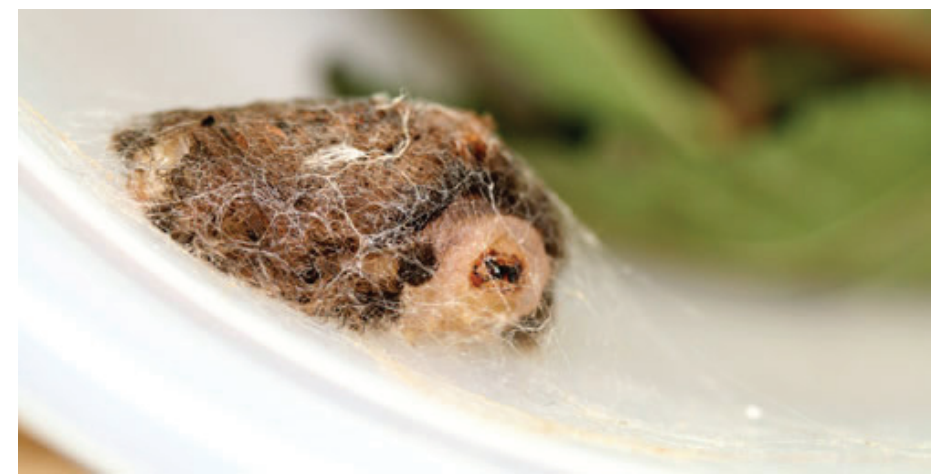

Figure 24. Southern flannel moth larva, Megalopyge opercularis, (initial stage of spinning cocoon).

Credits: Donald W. Hall, University of Florida.

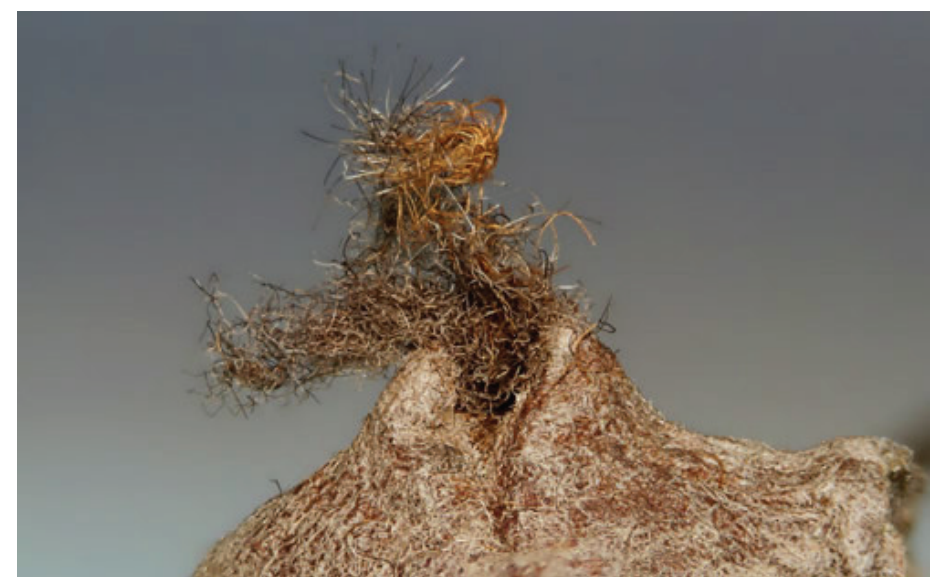

Figure 25. Southern flannel moth cocoon hair pocket, Megalopyge opercularis.

Credits: Donald W. Hall, University of Florida.

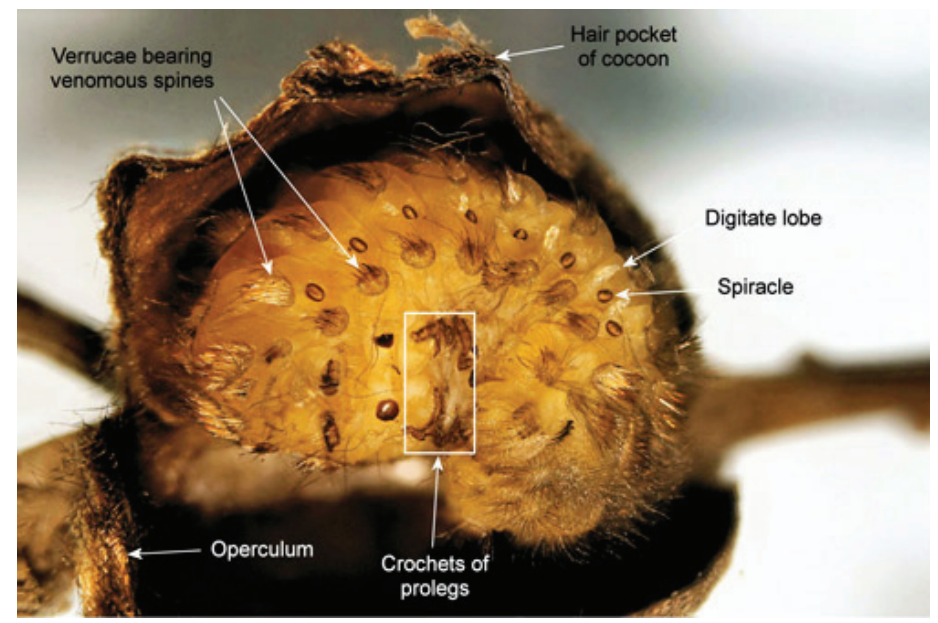

Figure 26. Southern flannel moth larva (pre-pupa), Megalopyge opercularis, (note venomous spines and post-spiracular appendages). Credits: Donald W. Hall, University of Florida.

The pharate adult (pre-adult) stage forces the operculum open by repeated alternating lengthening and shortening of the abdomen (Davidson 1967) - probably while hooking the dorsal bands of spines of the segments into the floor and inner surface of the operculum of the cocoon, thereby gradually moving the pharate adult forward and upward. Although they are not glued to the body, the legs remain folded and do not appear to assist in emergence from the cocoon.

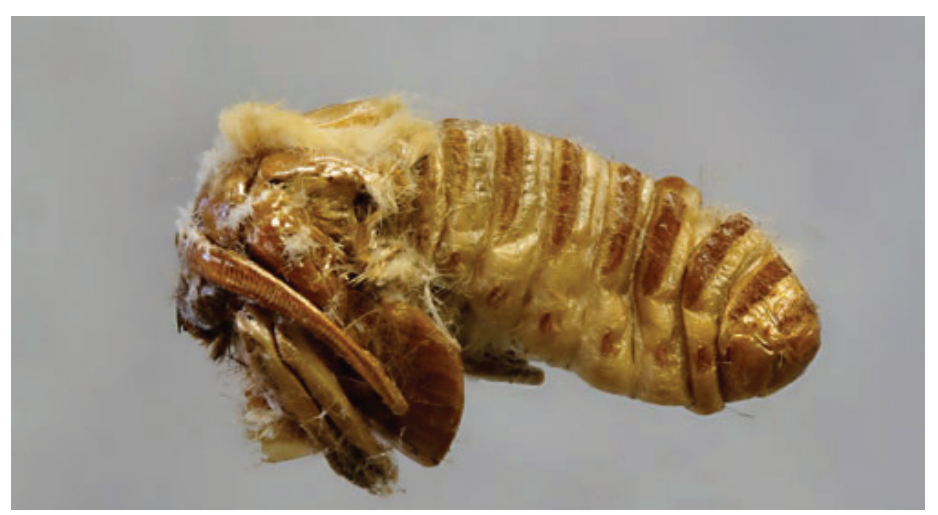

Figure 27. Southern flannel moth pharate adult, Megalopyge opercularis (note free appendages).

Credits: Donald W. Hall, University of Florida.

The rounded frons may assist in forcing open the cocoon (Epstein 1996) - presumably by pressing against the upper front edge of the cocoon as the operculum is being forced open. The expanded posterior margins of the occiput may function in a similar way by pressing against the operculum.

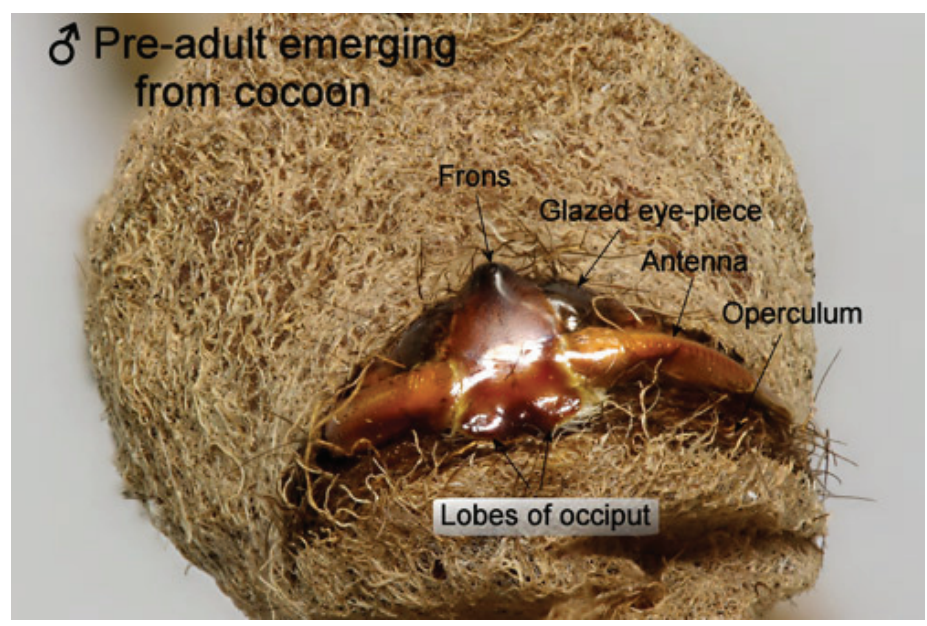

Figure 28. Southern flannel moth pharate adult, Megalopyge opercularis (beginning emergence from cocoon). Credits: Donald W. Hall, University of Florida.

Only when the pre-adult is nearly out of the cocoon does the adult moth split the pupal exoskeleton and emerge. The pupal exuviae is held by tension from the operculum and remains on the cocoon until it is beaten away by weathering. 


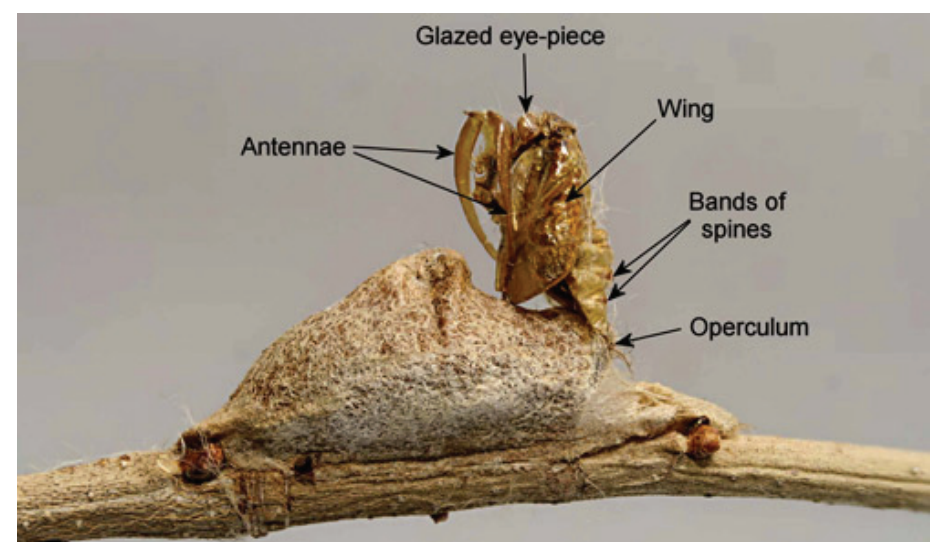

Figure 29. Southern flannel moth pupal exuviae, Megalopyge opercularis.

Credits: Donald W. Hall, University of Florida.

\section{Economic and Medical Improtance}

Occasionally, in outbreak years, puss caterpillars are sufficiently numerous to defoliate some trees (Bishopp 1923). However, their main importance is medical. In Texas, they have been so numerous in some years that schools in San Antonio in 1923 and Galveston in 1951 were closed temporarily because of stings to children (Diaz 2005).

The venomous spines of puss caterpillars are hollow and each is equipped with a venom gland at its base (Foot 1922). All larval instars, as well as exuviae, may sting but the toxicity of the stings increases with increasing size of the larvae (Davidson 1967).

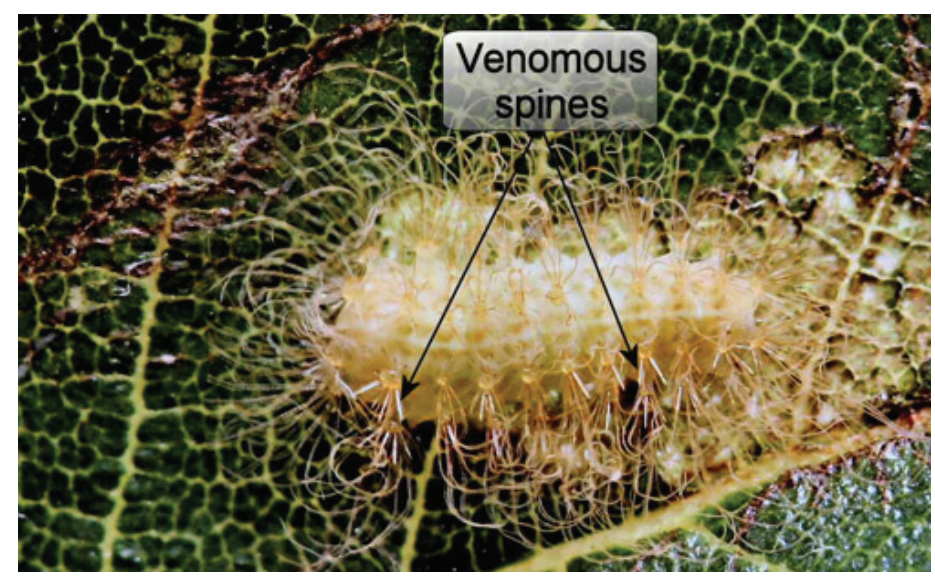

Figure 30. Puss caterpillar, Megalopyge opercularis (early instar showing venomous spines).

Credits: Donald W. Hall, University of Florida.

Foot (1922) reported that some individuals react more severely to stings than others, and the severity of the sting varies with the thickness of the skin where the sting occurs. The sting produces an immediate intense burning pain followed by the appearance of a red grid-like pattern on the skin that matches the pattern of the venomous spines on

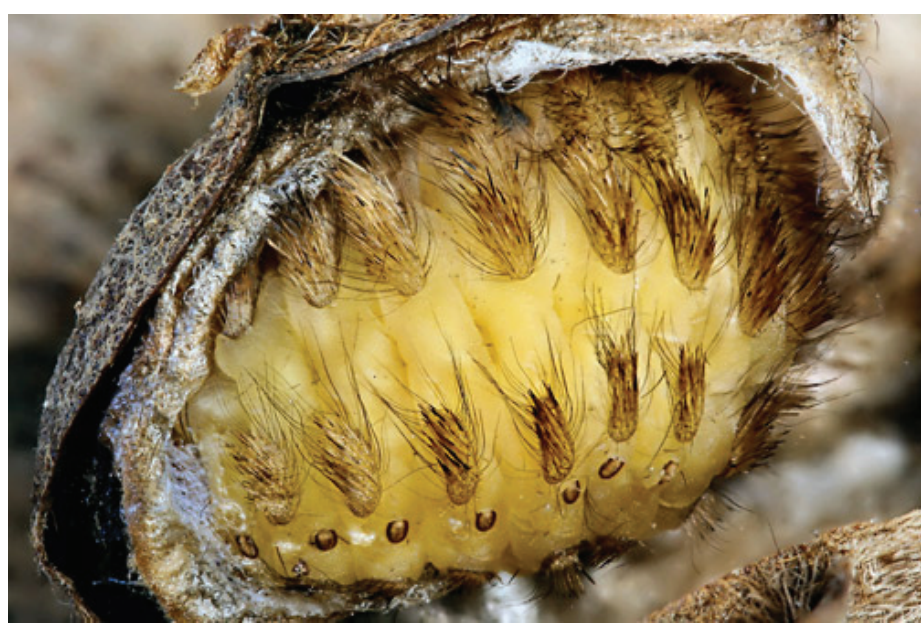

Figure 31. Puss caterpillar, Megalopyge opercularis (pre-pupa showing venomous spines).

Credits: Donald W. Hall, University of Florida.

the caterpillar. Swelling and sometimes also lymphadenopathy follow.

In addition to the characteristic localized symptoms, more general systemic manifestations may also occur including headache, fever, nausea, vomiting, tachycardia, low blood pressure, seizures and more rarely, abdominal pain, muscle spasms, and convulsions (Diaz 2005, Eagleman 2008, ElMallakh et al. 1986, Hossler 2010, McGovern 1961, Pinson and Morgan 1991).

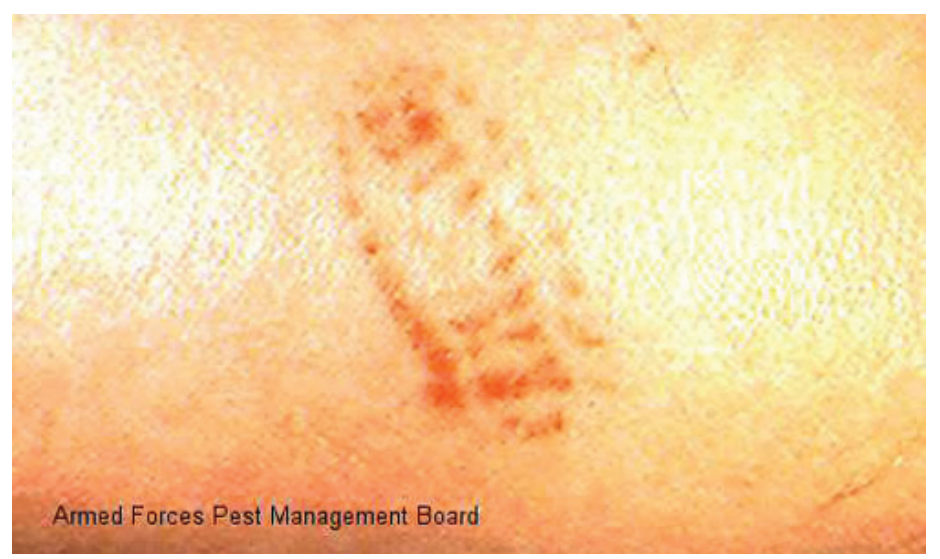

Figure 32. Puss caterpillar, Megalopyge opercularis (characteristic pattern of sting).

Credits: Courtesy of Armed Forces Pest Management Board.

The venom is not well-characterized but it has been shown to possess hemolytic activity, and there is evidence that it is proteinaceous based primarily on its precipitation by $75 \%$ saturated ammonium sulfate and the fact that it is inactivated by digestion with proteolytic enzymes (trypsin, pepsin, or chymotrypsin) (Picarelli and Valle 1971).

Eagleman (2008) has reviewed common treatments for puss caterpillar stings. Remedies that may be helpful in some cases include removing broken spine tips from the skin 
with tape, applying ice packs, use of oral antihistamine, application of hydrocortisone cream to the site of the sting, systemic corticosteroids, and intravenous calcium gluconate.

\section{Natural Enemies}

Khalaf (1975) observed Chrysopa sp. (Neuroptera: Chrysopidae) feeding on eggs and early instars. Khalaf (1975) also observed an Anolis lizard eat a 4th instar larva (about $5 \mathrm{~mm}$ long) after which it displayed gulping motions and rubbed its mouth against the ground. Larvae are probably attacked by a variety of generalist predators, but reported observations are lacking. Older instars are likely well-defended from vertebrate predators by their venomous spines.

At least four species of tachinid flies (Diptera: Tachinidae) have been reported from Megalopyge opercularis (Arnaud 1978, Khalaf 1975, Micks 1956, Patton 1956). O’Hara and Wood (2004) and O'Hara (2009) have updated the tachinid names from Arnaud (1978).

Table 1. Four species of tachinid flies.

\begin{tabular}{|c|c|}
\hline Names from Arnaud (1978) & Names from O'Hara (2009) \\
\hline Carcelia amplexa (Coquillett) & Carcelia amplexa (Coquillett) \\
\hline $\begin{array}{c}\text { Carcelia lagoae (Townsend) } \\
\text { Cuphorocera claripennis } \\
\text { (Macquart) }\end{array}$ & Chetogena claripennis (Macquart) \\
\hline Lespesia aletiae (Riley) & Lespesia aletiae (Riley) \\
\hline
\end{tabular}

Eggs of the tachinids are laid externally on the puss caterpillars. Most caterpillars are parasitized late enough that the flies mature in the cocoons. The adult flies then emerge by forcing open the operculum of the cocoon (Khalaf 1981).

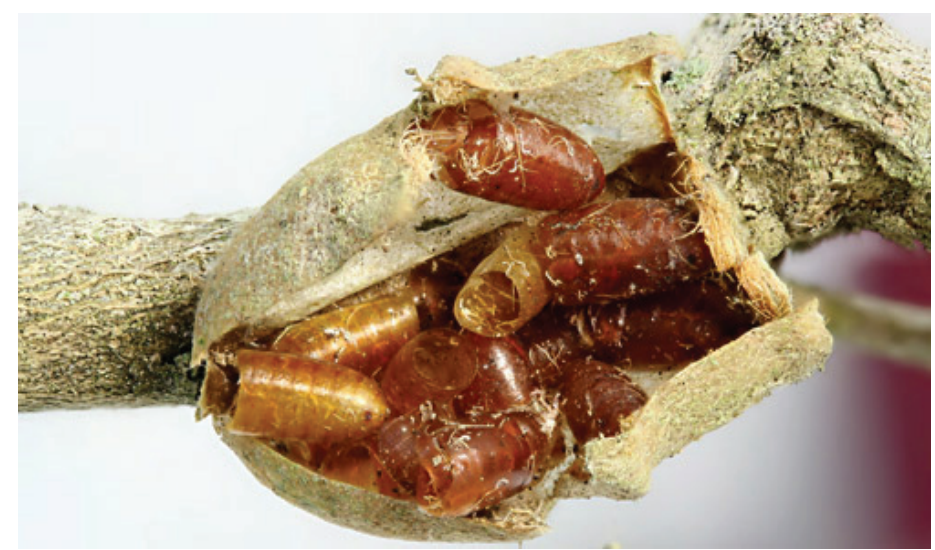

Figure 33. Tachinid puparial shells inside old Megalopyge opercularis cocoon.

Credits: Donald W. Hall, University of Florida.

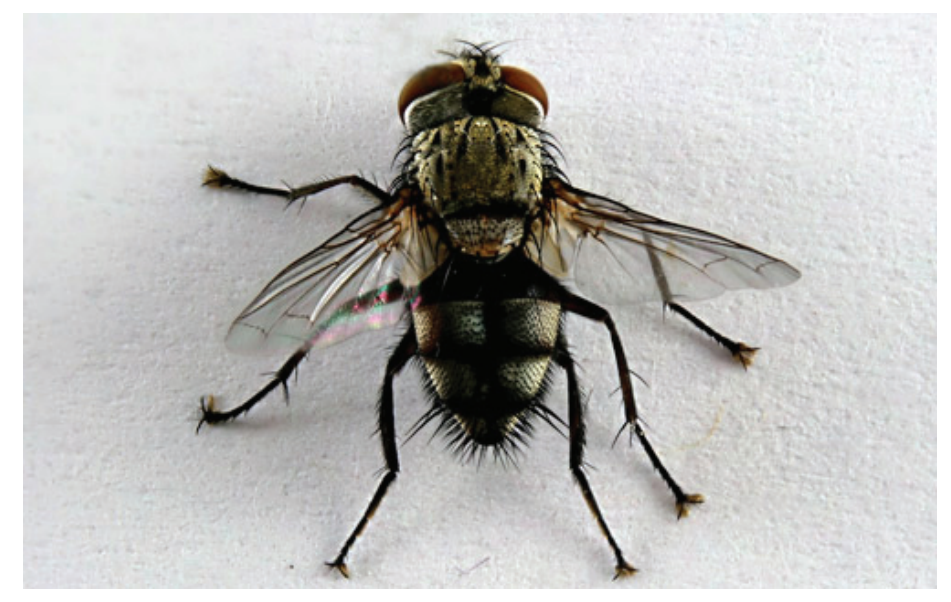

Figure 34. Adult tachinid fly that emerged from a Megalopyge opercularis cocoon.

Credits: Donald W. Hall, University of Florida.

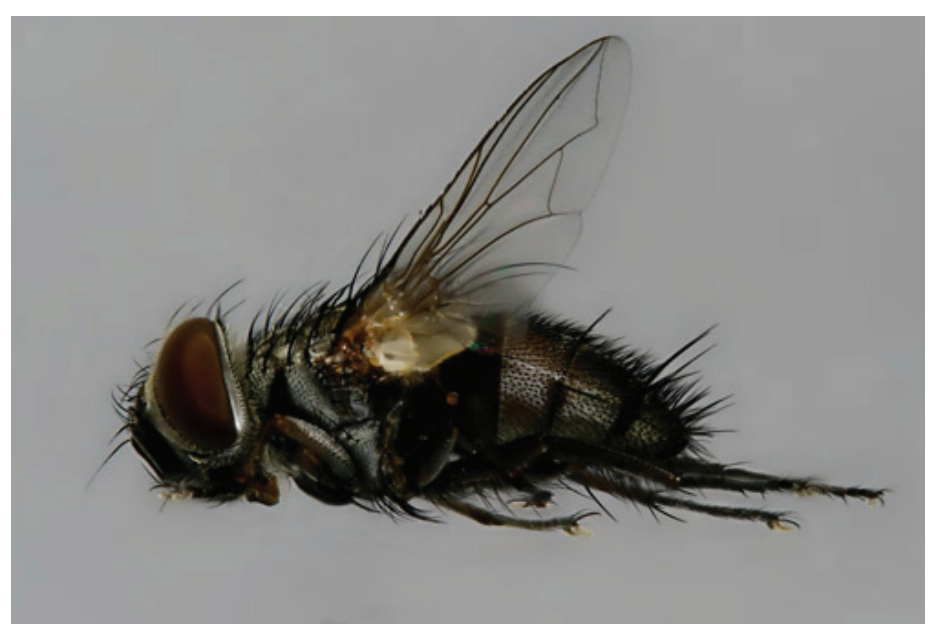

Figure 35. Adult tachinid fly (lateral view) that emerged from a Megalopyge opercularis cocoon.

Credits: Donald W. Hall, University of Florida.

Micks (1956) reported a parasitization rate of $20 \%$ in a population of Megalopyge opercularis in Galveston, Texas. There are similar rates of parasitism in Central Florida (DW Hall, unpublished data).

There are at least two ichneumonid wasp (Hymenoptera: Ichneumonidae) parasitoids of Megalopyge opercularis:

\section{Hyposoter fugitivus (Say)}

\section{Lanugo retentor (Brulle)}

Hyposotor fugitivus attacks and kills young larvae (Khalaf 1977). Lanugo retentor oviposits through the wall of the cocoon and is parasitic externally on prepupae or pupae (Khalaf 1975, Khalaf 1981). Full-grown Lanugo larvae make their own cocoons inside the Megalopyge cocoons and when mature, the adult wasps chew their way out of both cocoons making holes of 2-3 mm diameter. The holes in the Megalopyge cocoon are often but not always chewed through the operculum. 


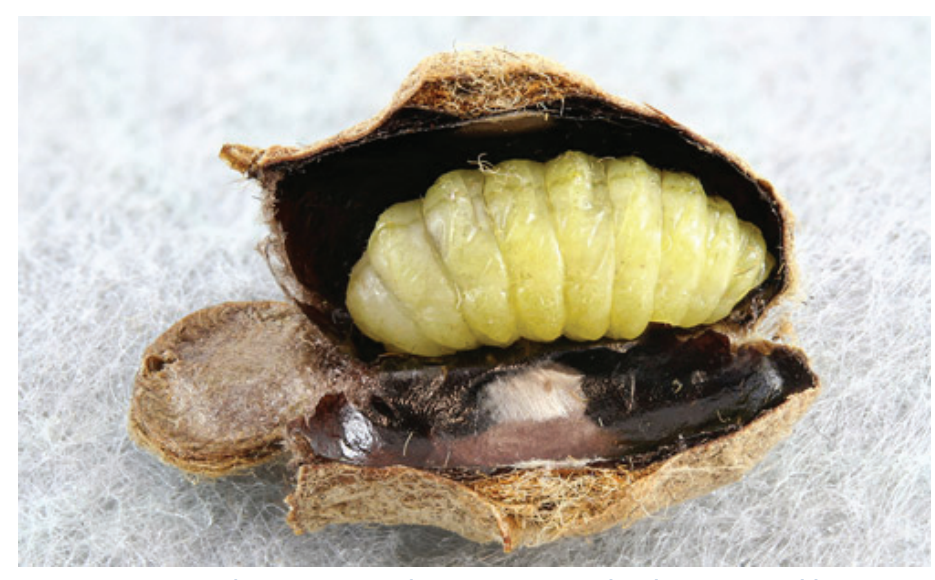

Figure 36. Megalopyge opercularis cocoon with ichneumonid larva probably Lanugo retentor.

Credits: Donald W. Hall, University of Florida.

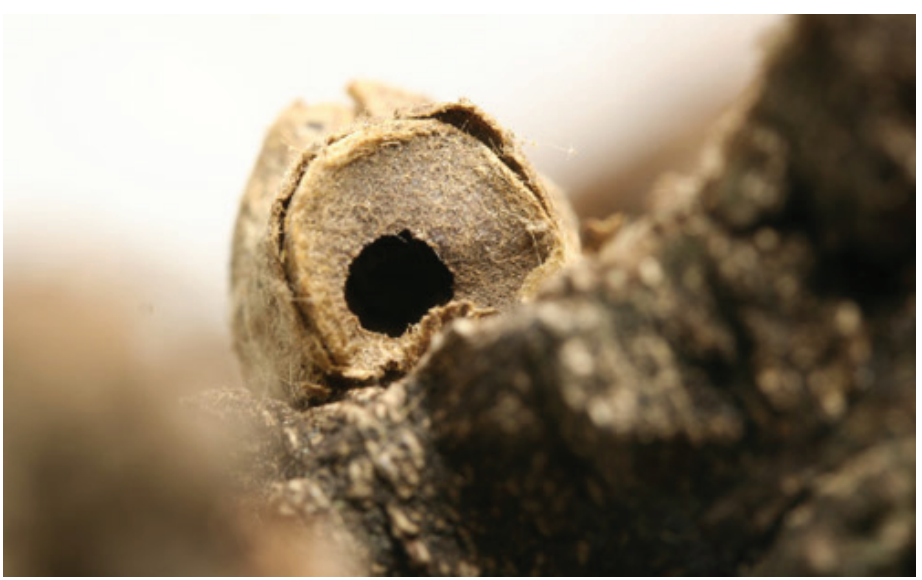

Figure 37. Megalopyge opercularis cocoon with exit hole in operculum probably made by the ichneumonid Lanugo retentor.

Credits: Donald W. Hall, University of Florida.

Khalaf (1975) reported a parasitization rate of $50 \%$ by Lanugo retentor in a population of Megalopyge opercularis in New Orleans, Louisiana.

Puss caterpillars have several behaviors that may help them escape natural enemies. After molting, the larvae eat their exuviae - including the setae and venomous spines. Some parasitoids of other insects have been demonstrated to

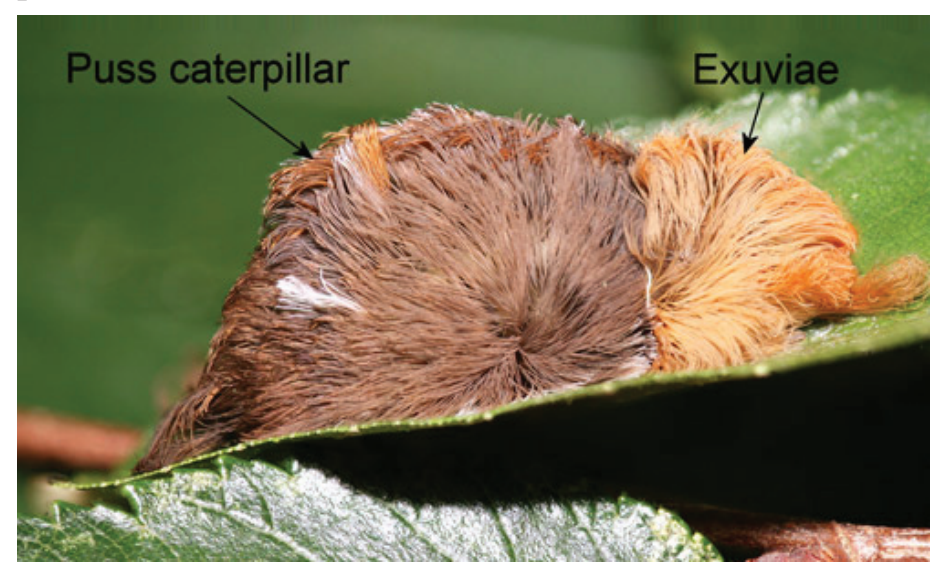

Figure 38. Megalopyge opercularis eating its exuviae.

Credits: Donald W. Hall, University of Florida locate their hosts by chemical cues from the exuviae. The exuviae also likely provide some nutrition to the larvae.

Puss caterpillars propel their fecal pellets. This behavior may serve to get the feces off the food. However, there is evidence that predators and parasitoids of some insects may locate their prey or hosts by honing in on volatiles from the feces.

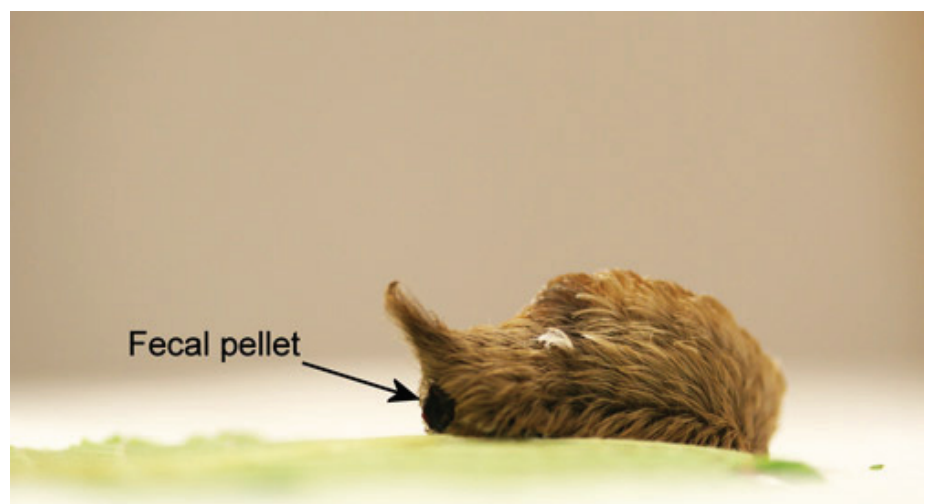

Figure 39. Puss caterpillar, Megalopyge opercularis, in the process of propelling its fecal pellet.

Credits: Donald W. Hall, University of Florida

\section{Control}

In most years, puss caterpillars are kept under control by natural enemies. If control measures are required, chemical insecticide or Bacillus thuringiensis applications recommended for control of other caterpillars (Osborne et al. 2012) should be effective.

\section{Cocoon Guests}

A wide variety of insects use the old abandoned cocoons as homes or temporary shelters - either entering through the front as the opercula sag with age or through the exit holes chewed by ichneumonid parasitoids. Two species of ants

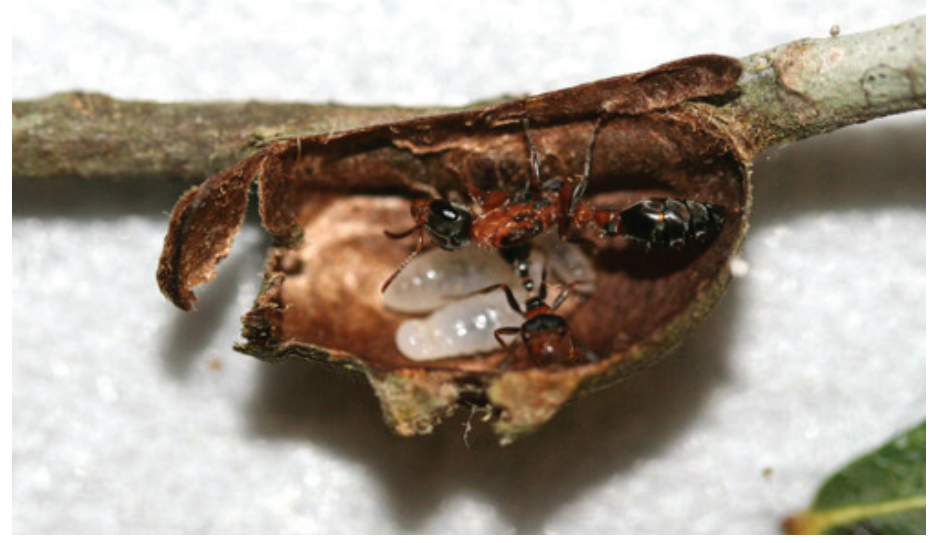

Figure 40. Pseudomyrmex gracilis (Fabricius) and brood inside old Megalopyge opercularis cocoon.

Credits: Donald W. Hall, University of Florida. 
have even been found raising brood inside the cocoons. Spiders are also common inhabitants of old cocoons.

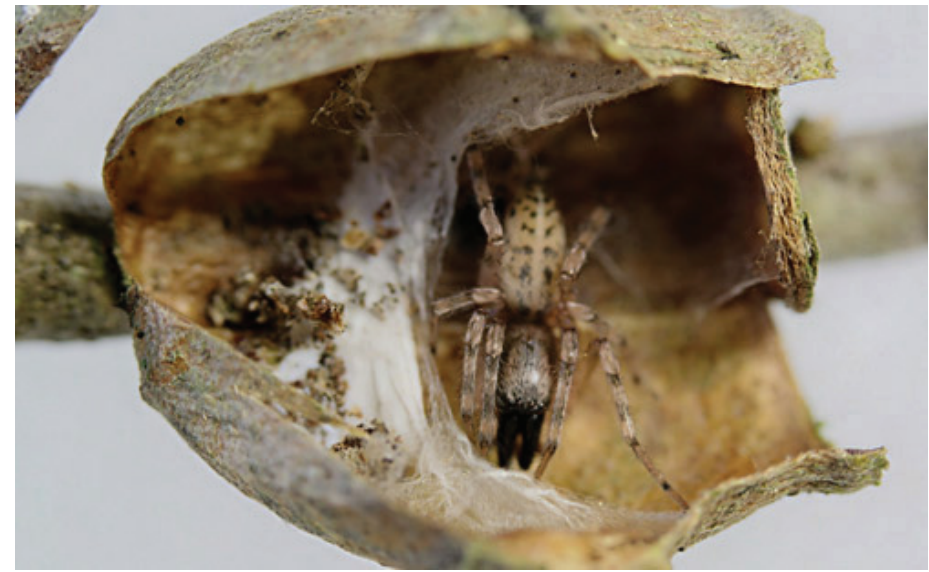

Figure 43. Unidentified spider inside old Megalopyge opercularis cocoon.

Credits: Donald W. Hall, University of Florida.

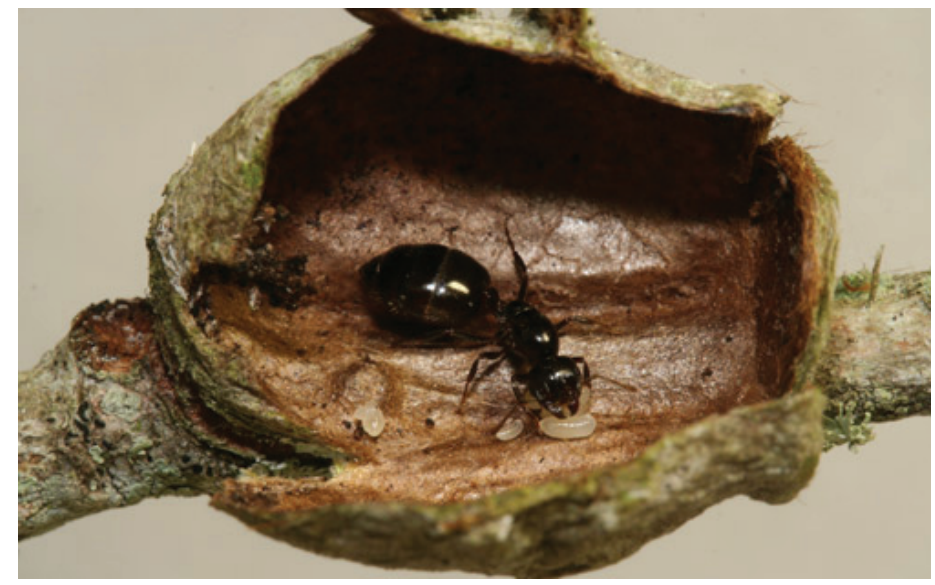

Figure 41. Crematogaster ashmeadi Mayr and brood inside old Megalopyge opercularis cocoon.

Credits: Donald W. Hall, University of Florida.

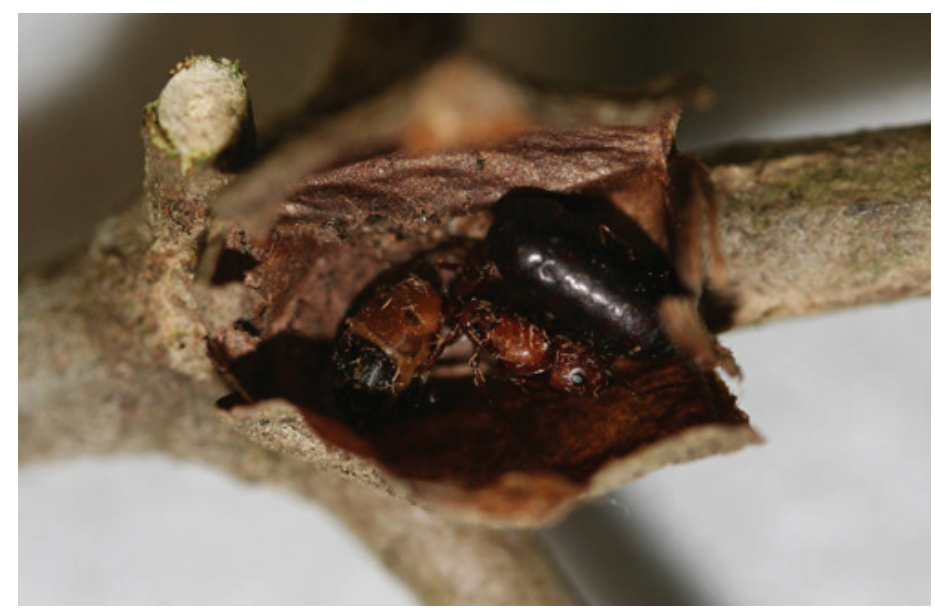

Figure 42. Camponotus snellingi Bolton and unidentified tachinid puparial shell inside old Megalopyge opercularis cocoon. Credits: Donald W. Hall, University of Florida.

\section{Selected References}

- Arnaud PH. 1978. A Host-Parasite Catalog of North American Tachinidae (Diptera). United States Department of Agriculture Miscellaneous Publication 1319. Washington, D.C. Updated names for this catalog are available online.

- Bishopp FC. 1923. The puss caterpillar and the effects of its sting on man. United States Department of Agriculture. Department Circular 288. 14 pp.

- Borror DJ. 1960. Dictionary of Word Roots and Combining Forms. Mayfield Publishing Company. Palo Alto, California. 134 pp.

- Covell CV. 2005. A Field Guide to Moths of Eastern North America. Special Publication Number 12. Virginia Museum of Natural History. Martinsville, Virginia. 496 pp.

- Davidson FF. 1967. Biology of laboratory-reared Megalopyge opercularis Sm. \& Abb. Morphology and histology of the stinging mechanism. Texas Journal of Science 19(3): 258-274.

- Diaz JH. 2005. The evolving global epidemiology, syndromic classification, management, and prevention of caterpillar envenoming. American Journal of Tropical Medicine and Hygiene 72: 347-357.

- Eagleman DM. 2008. Envenomation by the asp caterpillar (Megalopyge opercularis). Clinical Toxicology 46: 201-205.

- El-Mallakh RS, Baumgartner MS, Fares N. 1986. "Sting” of the puss caterpillar, Megalopyge opercularis (Lepidoptera: Megalopygidae): first report of cases from Florida and review of literature. The Journal of the Florida Medical Association 73(7): 521-525.

- Epstein ME. 1996. Revision and phylogeny of the limacodid-group families, with evolutionary studies on slug caterpillars (Lepidoptera: Zygaenoidea). Smithsonian Contributions to Zoology. Number 582. 102 pp.

- Foot NC. 1922. Pathology of the dermatitis caused by Megalopyge opercularis, a Texan caterpillar. Journal of Experimental Medicine 35: 737-753.

- Gordh G, Headrick DH. 2001. A Dictionary of Entomology. CABI Publishing. New York, New York. 1032 pp. 
- Heppner JB. 2003. Lepidoptera of Florida. Part 1. Introduction and Catalog. Volume 17 of Arthropods of Florida and Neighboring Land Areas. Division of Plant Industry. Florida Department of Agriculture and Consumer Services. Gainesville, Florida. 670 pp.

- Heppner JB. 1997. Urticating caterpillars in Florida: 3. Puss caterpillar and flannel moths (Lepidoptera: Megalopygidae). Florida Department of Agriculture and Consumer Services, Division of Plant Industry. Gainesville, Florida. Entomology Circular No. 381.2 pp.

- Hoffman F. 1932. Beitrage zur Naturgeschichte Brasilianischer Schmetterlinge. Deutsche Entomologische Zeitschrift 1932: 97-148.

- Hossler EW. 2010. Caterpillars and Moths. Part II. Dermatologic manifestations of encounters with Lepidoptera. Journal of the American Academy of Dermatology 62: 13-28.

- Khalaf KT. 1974. Nonaseptic wheat germ diet for Megalopyge opercularis. (Lepidoptera: Megalopygidae). Florida Entomologist 57: 377-381.

- Khalaf KT. 1975. Biology of the puss caterpillar and its ichneumonid parasite. Loyola University Press. New Orleans, Louisiana. 43 pp.

- Khalaf KT. 1977. Hypositor fugitivus (Ichneumonidae) parasitic within Megalopyge opercularis larvae (Megalopygidae). Journal of the Lepidopterists' Society 31: 147-148.

- Khalaf KT. 1981. Multiparasitism of puss caterpillar by a wasp and fly species (Lepidoptera: Megalopygidae). Florida Entomologist 64: 534-537.

- Khalaf KT. 1984. The identity of wing hairs in Megalopygidae. Journal of the Lepidopterists' Society 38: 64.

- Lintner JA. 1869. Transformations of Lagoa crispata Packard. Twenty-third Annual Report of the New York State Cabinet of Natural History. Appendix D. Entomological Contributions by Lintner JA. X pp. 138-145.

- McGovern JP, Barkin GD, McElhenney TR, Wende R. 1961. Megalopyge opercularis: observations of its life history, natural history of its sting in man, and report of an epidemic. Journal of the American Medical Association 175(13): 1155-1158.
- Micks DW. 1956. Laboratory rearing of the puss caterpillar, with notes on the incidence of parasitism. Journal of Economic Entomology 49: 37-39.

- Mosher E. 1916. A classification of the Lepidoptera based on characters of the pupae. Bulletin of the Illinois State Laboratory of Natural History 12:17-159.

- O'hara JE, Wood DM. 2004. Catalogue of the Tachinidae (Diptera) of North America north of Mexico. Associated Publishers. Gainesville, Florida. 410 pp.

- Ohara JE. 2009. Update of Tachinid Names in Arnaud (1978). (Last update: 7 July 2009)

- Osborne LS, Buss EA, Mannion CM, Price JF. 2012. Commercial foliage and woody ornamental arthropod pest management. ENY-311 (revised June, 2006). Entomology and Nematology Department,. Florida Cooperative Extension Service, Institute of Food and Agricultural Sciences, University of Florida.

- Packard AS. 1894. A study of the transformations and anatomy of Lagoa crispata, a bombycine moth. Proceedings of the American Philosophical Society 32(143): 275-292.

- Patton CN. 1956. The Larvaevoridae of Florida, with Notes on their Biology and Host Relationships. M.S. Thesis. University of Florida. Gainesville, Florida. 66 pp.

- Picarelli ZP, Valle JR. 1971. Pharmacological studies on caterpillar venoms. In: Bucherl W, Buckley EE. Venomous Animals and their Venoms. Volume 3., pp 103-118. Academic Press. New York, New York.

- Pinson RT, Morgan JA. 1991. Envenomation by the puss caterpillar (Megalopyge opercularis). Annals of Emergency Medicine 20(5): 562-564.

- Smith JE. 1797. The Natural History of the Rarer Lepidopterous Insects of Georgia. Vol. 2, Printed by Bensley T for Smith JE. London. 214 pp.

- Stehr FW. 1987. In Stehr FW. Immature Insects. Kendall/ Hunt Publishing Company. Dubuque, Iowa. pp. 454-456.

- Wagner DL. 2005. Caterpillars of Eastern North America. Princeton University Press. Princeton, New Jersey. 512 pp. 